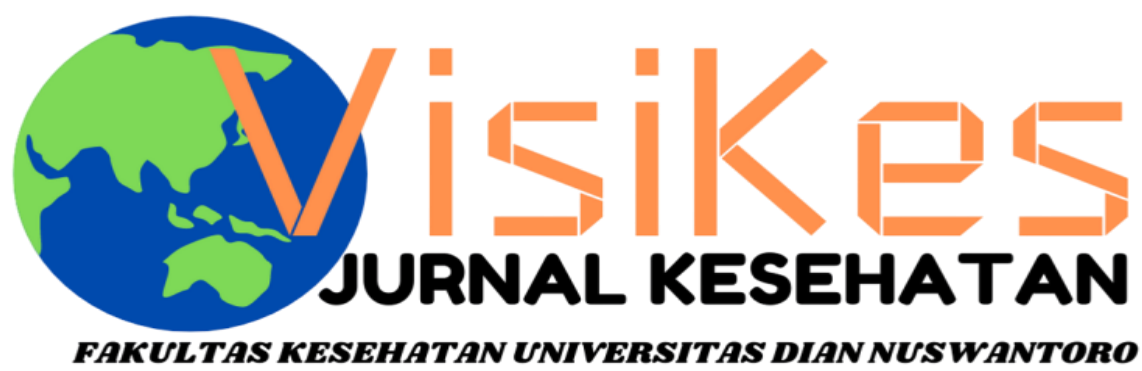

ISSN 1412-3746

FAKULTAS KESEHATAN UNIVERSITAS DIAN NUSWANTORO

Persepsi Mahasiswa Keperawatan Tentang Eskalasi Tenaga Perawat

Rendi Ariyanto Sinanto', Vivi Retno Intening ${ }^{2}$

Risiko kesehatan $\mathrm{Pb}$ dan $\mathrm{Hg}$ pada sayuran di desa Kopeng Kabupaten Semarang

Indira Casheila Anindityo ${ }^{1}$, Nur Endah Wahyuningsih ${ }^{2}$, Yusniar Hanani Darundiati ${ }^{3}$

Analisis Pelaksanaan Program Indonesia Sehat Dengan Pendekatan Keluarga (Pispk) Dalam Capaian Indeks Keluarga

Sehat Di Kabupaten Brebes Tahun 2020 Studi Pada Puskesmas Kluwut Kabupaten Brebes

Rizky Aprilianti Lestari ${ }^{1}$ dr. Antono Suryoputro ${ }^{1}$ Dr. dr. Apoina Kartini. M. Kes ${ }^{1}$

Disiplin Keselamatan dan Kesehatan Kerja melalui pemakaian alat pelindung diri di laboratorium kimia PT Sucofindo

Jakarta

Susan Endah Kartikasari ${ }^{1}$, Tatan Sukwika ${ }^{2}$

Perbedaan Pengetahuan Anemia dan Tablet Tambah Darah (TTD) Sebelum dan Sesudah Pendidikan Kesehatan Melalui

Media Video dan Aplikasi Quizlet

Devita Sari ${ }^{1}$, Gisely Vionalita ${ }^{2}$

Tingkat Pengetahuan Dan Perilaku Mahasiswi Mengenai Legalitas Dan Keamanan Kosmetik

Hani Sri Fitriani, Rizki Siti Nurfitria

Evaluasi Manajemen Dokumen Rekam Medis Di Filing Aktif Rumah Sakit Swasta Kabupaten Semarang

Bobby Anggara Laksana Putra ${ }^{1}$, Retno Astuti Setjaningsih ${ }^{2}$

Tingkat Pengetahuan Gizi Seimbang dan Profil Kesehatan Sopir Bus Antar Kota

Vilda Ana Veria Setyawati ${ }^{1}$, Bayu Yoni Setyo Nugroho ${ }^{1}$

Pengaruh Pengetahuan Dan Motivasi Kerja Terhadap Penerapan Early Warning Score System Di Rsup H Adam Malik Ita Riahna Pinem ${ }^{1}$, Zulfendri', Siti Saidah Nasution ${ }^{3}$

Analisis Penelusuran Masker Sebagai Protokol Kesehatan Saat Pandemi Covid-19 Di Indonesia: Studi Google Trends Ully Febra Kusuma ${ }^{1}$, Nurunnisa Arsyad ${ }^{2}$, Melissa Shalimar Lavinia ${ }^{3}$, Selvia Rahayu ${ }^{4}$, M. Khairul Kahfi , Rizma Adllia Syakurah ${ }^{6}$ Perilaku Hidup Bersih Dan Sehat (Phbs) Dengan Kejadian Sakit Pada Siswa Sekolah Dasar Di Kabupaten Banyumas Windri Lesmana Rubai ${ }^{1}$, Pramesthi Widya Hapsari', Katri Andirini Surijati ${ }^{3}$

Identifikasi Risiko Ganguan Muskuloskletal Pada Pekerja Percetakan Dengan Metode Nordic Body Map

Octavianus Hutapea ${ }^{1}$, Moch.Sahri', Rustam Basuki ${ }^{3}$

Literatur review: Implementasi Bauran Pemasaran 7P Terhadap Tingkat Kepuasan Pasien Di Rumah Sakit

Desi Natalia Marpaung ${ }^{1}$ Ernawaty $^{2}$ Diansanto Prayoga ${ }^{3}$ Syifa'ul Lailiyah $^{4}$

Kelengkapan Informasi Medis Untuk Mendukung Kodefikasi Penyakit Jantung Guna Mewujudkan Kualitas Data Informasi Medis Di Rumah Sakit Islam Sultan Agung Semarang

Dyah Ernawati ${ }^{1}$, Ratna Rifatul Ulya ${ }^{2}$, Arif Kurniadi ${ }^{3}$

Kajian Faktor Kendala Dokter Tidak Menggunakan Aplikasi Wifi Tb Di Kota Semarang

Arif Kurniadi', Evina Widianawati2, Dyah Ernawati ${ }^{3}$

Analisis Pelaksanaan Program Penanggulangan Tuberkulosis Paru Di Puskesmas Purwoyoso Kota Semarang

Nahari Ratu Cempaka Wilis ${ }^{1}$ Hardi Warsono ${ }^{2}$ M. Sakundarno Adi ${ }^{3}$

Hubungan Penggunaan Alat Pelindung Diri (Apd) Dengan Kadar Sgot Dan Sgpt Dalam Darah Pada Petani Padi

Iga Maliga, Rafi'ah

Faktor Risiko Kejadian Stunting Pada Balita di Wilayah Kerja Puskesmas Pandan Kabupaten Sintang

${ }^{1}$ Agustini Elisabet, ${ }^{2}$ Elvi Juliansyah

Peran Suami Dan Petugas Kesehatan Dengan Deteksi Dini Kanker Serviks

Christina Leasa, ${ }^{1}$ Mariene Wiwin Dolang

Analisis Penerapan Protokol Kesehatan terhadap Tingkat Kepatuhan Pada Pekerja informal Selama Pandemi Covid-19

MG Catur Yuantari ${ }^{1}$, Enny Rachmani ${ }^{2}$, Eti Rimawati ${ }^{1}$, Sri Handayani ${ }^{1}$, Edi Jaya Kusuma ${ }^{2}$

Peran Pengawas Minum Obat Dan Pendampingan Berobat Ulang Dengan Keberhasilan Pengobatan Tb Paru

Taswin $^{\left.1^{*}\right)}$, (zan $^{1)}$, Wahyuddin $^{1)}$, Dahmar ${ }^{1)}$

Faktor Determinan Sosial Dan Gambaran Kejadian Post Traumatic Syndrome Disorder (Ptsd) Pasca Banjir Di Dki Jakarta

Dan Bekasi Tahun 2020

Thresya Febrianti ${ }^{1}$, Nurfadhillah ${ }^{2}$, Mitha Nurhjanah ${ }^{3}$, Tiara Kautsa Aliefya ${ }^{4}$

Perbedaan Pola Makan Pada Balita Stunting Dan Tidak Stunting Di Kecamatan Teon Nila Serua (Tns) Kabupaten Maluku Tengah

Trixie Leunupun ${ }^{1}$, Ani Margawati' ${ }^{2}$ Annastasia Ediati ${ }^{3}$

Gambaran Pengelolaan Rekam Medis Rawat Inap Di Rsud Syekh Yusuf Kab. Gowa Tahun 2019

Zilfadhilah Arranury*, Surahmawati, Muhammad Rusmin, Tri Addya Karini, Dian Rezki Wijaya, Ranti Ekasari, Jihan Sulfitri

Analisis Risiko Kesehatan dalam Pemanfaatan Kemball Limbah Sludge Industri Makanan PT. X

Sri Slamet Mulyati ${ }^{1}$, Fajar Sihite ${ }^{2}$ 


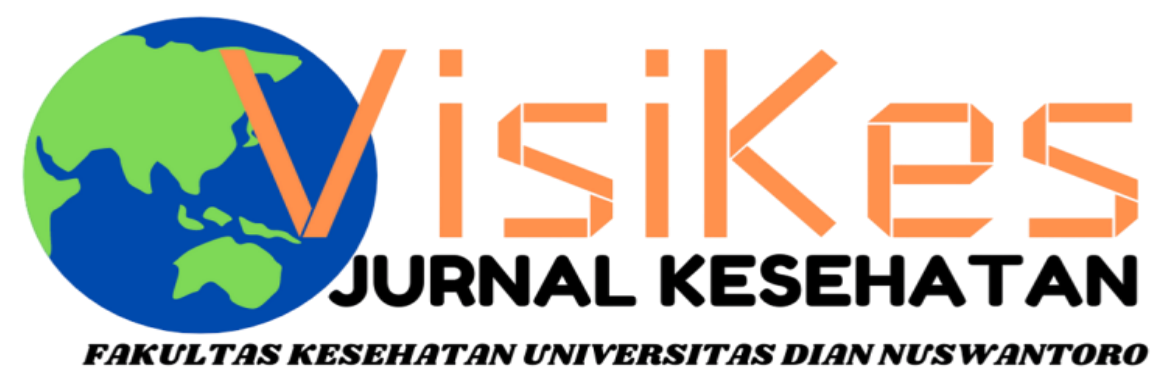

Volume 20, Nomor 1, April 2021

\section{Ketua Redaksi}

Dr. Drs. Slamet Isworo, M.Kes

\section{Penyunting}

Enny Rachmani, SKM, M.Kom, Ph.D

Fitria Wulandari, SKM, M.Kes

\section{Sekretariat}

Lice Sabata, SKM

Desain dan Layout

Puput Nur Fajri, SKM

\section{Alamat Redaksi}

Fakultas Kesehatan Universitas Dian Nuswantoro Jl. Nakula I No. 5-11 Semarang Telp/fax. (024) 3549948

email : visikes@fkes.dinus.ac.id

website $\quad$ : http://publikasi.dinus.ac.id/index.php/visikes/index

VisiKes diterbitkan mulai Maret 2002

Oleh Fakultas Kesehatan Universitas Dian Nuswantoro 


\title{
Kelengkapan Informasi Medis Untuk Mendukung Kodefikasi Penyakit Jantung Guna Mewujudkan Kualitas Data Informasi Medis Di Rumah Sakit Islam Sultan Agung Semarang
}

\author{
Dyah Ernawati ${ }^{1}$, Ratna Rifatul Ulya ${ }^{2}$, Arif Kurniadi ${ }^{3}$ \\ 1,2,3 Program Studi D3 Rekam Medis dan Informasi Kesehatan Fakultas Kesehatan Universitas Dian \\ Nuswantoro Semarang
}

\begin{abstract}
The completeness of the medical information contained in the Medical Record Document (DRM), especially in cases of heart disease, is very necessary because of the continuity of medical information to see which diagnosis consumes the most resources during an episode of hospital care, and then for the basis for determining the main diagnosis code with using the ICD-10. The results of observations at the Sultan Agung Islamic Hospital Semarang, found that the information in the history sheet was incomplete, as well as the doctor when writing the main diagnosis, there was more than one diagnosis. So the coder officer had to do an analysis of medical record sheets, to determine which was the primary code and secondary code using the re-selection rule if the doctor could not be confirmed. These findings can have an impact on reporting, where the primary diagnosis is only written 1 diagnosis, while the secondary diagnosis may be written more than 1 diagnosis. This study aims to analyze the completeness of medical record documents that support the determination of heart disease codes at the Sultan Agung Islamic Hospital Semarang.

This type of research is descriptive with a cross-sectional approach. The object of the research was the document of inpatient medical records for BPJS patients with heart disease, and the research subject was inpatient coder. The data were collected using interview techniques and DRM observation using a cardiac diagnosis checklist. Data were analyzed using descriptive analysis techniques supported by content validity techniques.

The results of the quantitative analysis review on 27 DRM samples in patients with BPJS heart disease, showed that the greatest completeness of quantitative analysis lies in the identification review, namely 22 (81.5\%) documents and the largest incompleteness in the authentication review, namely 15 (55.6\%) documents. Greatest consistency in analysis qualitative information contained in the informed consent review, namely 27 (100\%) DRM and the greatest inconsistency in the review of the consistency of recording things that were done during treatment and care, namely 7 (25.9\%) DRM. Suggestions for medical personnel as health care providers for patients, especially BPJS patients, heart disease, pay attention to filling in complete medical record documents to improve the quality of medical record services and support hospital reporting.
\end{abstract}

Keywords: Medical Record Documents, Quantitative Reviews, Qualitative Reviews, Heart Disease, BPJS patients

\begin{abstract}
ABSTRAK
Kelengkapan informasi medis yang terdapat dalam Dokumen Rekam Medis (DRM), khususnya pada kasus penyakit jantung, sangat diperlukan karena kesinambungan informasi medis untuk melihat diagnosis mana yang paling banyak menghabiskan resource selama episode perawatan di Rumah Sakit, dan selanjutnya untuk dasar penetapan kode diagnosis utama dengan menggunakan ICD-10. Hasil observasi di RS Islam Sultan Agung Semarang, ditemukan adanya informasi dalam lembar anamnesis yang tidak lengkap, serta dokter dalam melakukan pencatatan penulisan diagnosis utama, terdapat lebih dari satu diagnosis. Sehingga petugas coder harus melakukan analisis lembar-lembar rekam medis, untuk menentukan mana yang kode utama dan kode sekunder dengan menggunakan aturan re-seleksi jika dokter tidak dapat dikonfirmasi. Temuan tersebut dapat berdampak pada pelaporan, dimana diagnosis utama hanya tertulis 1 diagnosis, sedangkan diagnosis sekunder boleh ditulis lebih dari 1 diagnosis. Penelitian bertujuan untuk menganalisis kelengkapan dokumen rekam medis yang mendukung penetapan kode penyakit jantung di Rumah Sakit Islam Sultan Agung Semarang.
\end{abstract}


Jenis penelitian deskriptif dengan pendekatan cross-sectional. Objek penelitian adalah dokumen rekam medis rawat inap pasien BPJS penyakit jantung, dan subyek penelitian adalah coder rawat inap. Pengumpulan data menggunakan teknik wawancara pada dan observasi DRM dengan menggunakan lembar checklist diagnosis jantung. Data dianalisis menggunakan teknik analisis deskriptif yang didukung dengan teknik validitas konten.

Hasil review analisis kuantitatif pada 27 sampel DRM pada pasien BPJS penyakit jantung, menunjukkan kelengkapan terbesar analisis kuantitatif terletak pada review identifikasi yaitu 22 $(81,5 \%)$ dokumen dan ketidaklengkapan terbesar pada review autentikasi yaitu $15(55,6 \%)$ dokumen. Kekonsistenan terbesar pada analisis kualitatif terdapat pada review informed consent yaitu $27(100 \%)$ DRM dan ketidakkonsistenan terbesar pada review konsistensi pencatatan hal-hal yang dilakukan saat pengobatan dan perawatan yaitu 7 (25,9\%) DRM. Saran untuk tenaga medis sebagai pelaksana asuhan kesehatan pada pasien, khususnya pasien BPJS, penyakit jantung, agar memperhatikan pengisian kelengkapan dokumen rekam medis untuk meningkatkan mutu pelayanan rekam medis dan menunjang pelaporan Rumah Sakit.

Kata kunci: Dokumen Rekam Medis, ReviewKuantitatif, Review Kualitatif, Penyakit Jantung, pasien BPJS

\section{PENDAHULUAN}

Rumah Sakit adalah institusi pelayanan bidang kesehatan, yang menyediakan fasilitas pelayanan kesehatan, dimulai dari pelayanan gawat darurat, pelayanan rawat jalan dan pelayanan rawat inap secara perorangan dan paripurna. ${ }^{(10)}$ Seiring dengan tuntutan pelayanan yang dapat menyentuh semua lapisan masyarakat, maka Rumah Sakit menjalin bekerja sama dengan BPJS (Badan Penyelenggara Jaminan Sosial Kesehatan) Kesehatan untuk menerapkan pembayaran atas perawatan dan pengobatan pasien melalui prospectif payment yaitu casemix. Casemix merupakan sistem pembayaran berdasarkan penggolongan kasus yang telah ditetapkan oleh BPJS. Dan dalam proses pembayarannya, pihak BPJS terhadap Rumah Sakit dilakukan dengan cara pengajuan klaim BPJS pasien, maka dari itu klaim tersebut haruslah tepat dan relevan dengan dokumen rekam medis pasien. Dalam dokumen rekam medis, kelengkapan informasi medis untuk dasar penetapan kode penyakit dan tindakan menjadi perhatian penuh dan harus dipenuhi pengisian kelengkapananya.

Rekam medis adalah berkas yang berisi catatan dan dokumen yang berupa identitas pasien, pemeriksaan, pengobatan, tindakan dan pelayanan kesehatan lainnya yang telah diberikan kepada pasien selama episode perawatan ${ }^{(11)}$. Kelengkapan informasi dalam rekam medis yaitu memuat informasi seperti adanya lembar resume, lembar hasil pemeriksaan penunjang, lembar tindakan dan operasi apabila ada. Informasi yang terdapat dalam resume medis merupakan ringkasan seluruh masa pengobatan dan perawatan oleh para tenaga kesehatan dan pihak terkait yang memberi asuhan kesehatan selama pasien dirawat. Dengan kelengkapan informasi pada lembar-lembar dokumen rekam medis ini dapat mempengaruhi mutu pelayanan serta dapat menunjang penetapan kode diagnosis penyakit dan prosedur medis, yang berpengaruh dibidang manajemen data klinis dan tagihan pembiayaan berkaitan dengan asuhan dan layanan kesehatan yang telah 
diberikan kepada pasien selama episode perawatan di Rumah Sakit.

\section{RS Islam Sultan Agung Semarang} merupakan Rumah Sakit Islam type B Pendidikan di Kota Semarang yang memiliki pelayanan diantaranya, unit rawat jalan, unit rawat inap, unit gawat darurat dan pelayanan penunjang lainnya. Layanan unggulan yang terdapat di Rumah Sakit ini, salah satunya adalah Cardiac Center atau spesialisasi Penyakit Jantung. Dan Rumah Sakit ini menjadi rujukan bagi Rumah Sakit - Rumah Sakit dengan type C. Berdasarkan survei awal melalui wawancara dengan salah satu coder RS Islam Sultan Agung yang menuturkan bahwasannya pada kasus-kasus Penyakit Jantung pasien rawat inap, masih terdapat adanya informasi anamnesis yang tidak lengkap, serta kurang spesifik pencatatan dokter dalam rekam medis yaitu pada penulisan diagnosis utama, ditulis lebih dari satu diagnosis. Sedangkan pada pelaporan diagnosis utama adalah satu, sedangkan untuk diagnosis sekunder boleh lebih dari satu. Sehingga petugas coder perlu melakukan konfirmasi pada dokter penanggung jawab pasien (DPJP) atau jika tidak dapat dikonfirmasi maka coder melakukan analisa lembar-lembar rekam medis, untuk mengecek ulang kesinambungan informasi medis untuk melihat diagnosis mana yang paling banyak menghabiskan resource selama episode perawatan di Rumah Sakit, yang selanjutnya dipilih sebagai diagnosis utama, dengan menggunakan teori aturan re-seleksi RULE MB ICD-10. Hasil Analisa Kuantitatif berdasarkan review Identifikasi, Autentikasi, Pencatatan, dan Pelaporan menunjukkan prosentase sebanyak 90\% DRM tidak lengkap dan 10\% DRM lengkap. Dan hasil Analisa Kualitatif berdasarkan review Penulisan Diagnosis Spesifik, Kekonsistenan Penulisan Diagnosis, Pencatatan Perawatan dan Pengobatan, serta Informed Consent menunjukkan prosentase 50\% DRM tidak lengkap dan 50\% DRM lengkap.

\section{METODE PENELITIAN}

Jenis penelitian adalah deskriptif kuantitatif dengan melakukan analisis kelengkapan informasi medis pada dokumen rekam medis (DRM) dengan teori analisis review kuantitatif dan review kualitatif, khususnya pada kasus Penyakit Jantung pasien BPJS rawat inap. Rancangan penelitian yaitu cross-sectional. artinya, penelitian dilakukan dengan pengamatan sesaat dalam suatu periode tertentu dalam subjek studi hanya dilakukan satu kali pengamatan selama penelitian. Variabel penelitian dalah Analisis kuantitatif yang meliputi: (review identifikasi pasien, review pelaporan, review autentikasi, dan review pencatatan), Analisis kualitatif yang meliputi: (review penulisan diagnosis spesifik, review kekonsistenan penulisan diagnosis, review pencatatan hal-hal yang telah dilakukan saat pengobatan dan perawatan, dan review informed consent). Objek penelitian yaitu dokumen rekam medis (DRM) kasus Penyakit Jantung pasien BPJS rawat inap di RS Islam SA Semarang berjumlah 193 dokumen rekam medis. Namun DRM yang dapat terkumpul untuk diolah selanjutnya dianalisis sebanyak 27 dokumen rekam medis, diambil secara acak di unit assembling. Metode pengumpulan data 
adalah observasi dan wawancara. instrument penelitian menggunakan tabel ceklist analisa kelengkapan dokumen rekam medis. Analisis data dalam penelitian ini adalah analisis deskriptif untuk melakukan analisa secara apa adanya kemudian ditarik kesimpulan mengenai analisis kelengkapan DRM yang mendukung system pelaporan dan penetapan kode penyakit pada pasien jantung, rawat inap dan peserta BPJS di RS Islam SA Semarang.

\section{HASIL DAN PEMBAHASAN}

\section{A. Hasil}

1. Analisis Kuantitatif Dokumen Rekam Medis Pada Kasus Penyakit Jantung

Tabel 1. Hasil Analisis Kuantitatif Penyakit Jantung di RSI SA Semarang

\begin{tabular}{llcccc}
\hline \multirow{2}{*}{ No } & \multirow{2}{*}{ Review } & \multicolumn{2}{c}{ Lengkap } & \multicolumn{2}{c}{ Tidak Lengkap } \\
\cline { 3 - 6 } & & Total & $\%$ & Total & $\%$ \\
\hline 1 & Identifikasi & 21 & $77,8 \%$ & 6 & $22,2 \%$ \\
2 & Autentikasi & 12 & $44,4 \%$ & 15 & $55,6 \%$ \\
3 & Pencatatan & 19 & $70,4 \%$ & 8 & $29,6 \%$ \\
4 & Pelaporan & 22 & $81,5 \%$ & 5 & $18,5 \%$ \\
\hline
\end{tabular}

Berdasarkan analisa kuantitatif pada dokumen rekam medis rawat inap pasien BPJS kasus Penyakit Jantung di RS Islam Sultan Agung Semarang pada masingmasing review dapat diuraikan sebagai berikut:

a. Untuk review identifikasi menunjukkan $21(77,8 \%)$ lengkap dan $6(22,2 \%)$ tidak lengkap.

b. Untuk review autentikasi menunjukkan 12 (44,4\%) lengkap dan 15 (55,6\%) tidaklengkap. c. Untuk review pencatatan menunjukkan 19 (70,4\%) lengkap dan 8 (29,6\%) tidak lengkap.

d. Untuk review pelaporan menunjukkan $22(81,5 \%)$ lengkap dan $5(18,5 \%)$ tidak lengkap. Dari hasil tersebut dapat disimpulkan bahwa kelengkapan pada analisa kuantitatif terbanyak terdapat pada review pelaporan yaitu 22 $(81,5 \%)$ kelengkapan dan 5 (18,5\%) ketidaklengkapan.

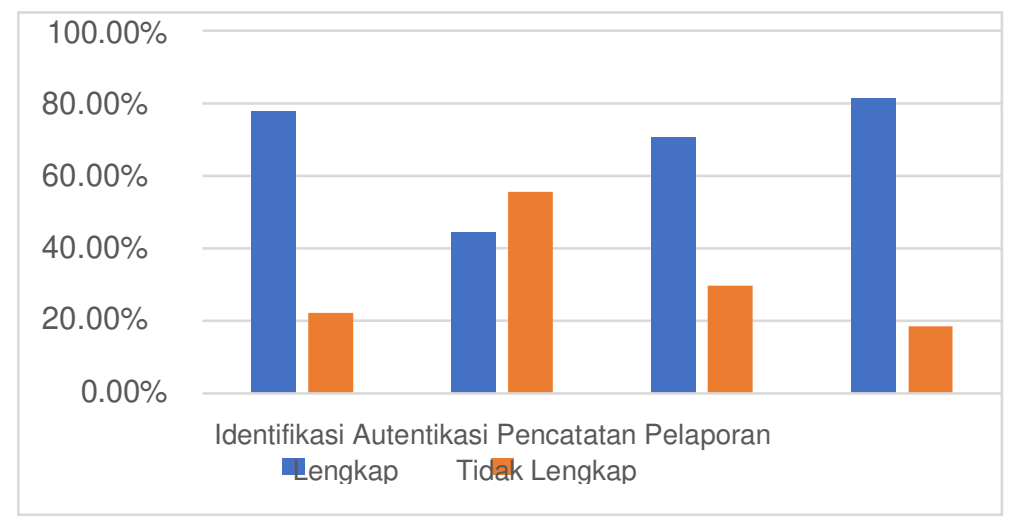

Gambar 1. Grafik Persentase Hasil Analisis Kuantitatif Dokumen Rekam Medis Penyakit Jantung di RS Islam Sultan Agung Semarang

2. Analisis Kualitatif Dokumen Rekam Medis Pada Kasus Penyakit Jantung 
Tabel 2. Hasil Analisis Kualitatif Dokumen Rekam Medis Penyakit Jantung di RSI SA Semarang

\begin{tabular}{|c|c|c|c|c|c|}
\hline \multirow{2}{*}{ NO } & \multirow{2}{*}{ Review } & \multicolumn{2}{|c|}{ Konsisten } & \multicolumn{2}{|c|}{ Tidak Konsisten } \\
\hline & & Total & $\%$ & Total & $\%$ \\
\hline & Penulisan diagnosis spesifik & 24 & $88,9 \%$ & 3 & $11,1 \%$ \\
\hline & $\begin{array}{l}\text { Kekonsistenan penulisan } \\
\text { diagnosis }\end{array}$ & 24 & $88,9 \%$ & 3 & $11,1 \%$ \\
\hline & $\begin{array}{l}\text { Kekonsistenan pencatatan hal- } \\
\text { hal yang telah dilakukan saat pengobatan dan perawatan }\end{array}$ & 20 & $74,1 \%$ & 7 & $25,9 \%$ \\
\hline & Adanya informed consent & 27 & $100 \%$ & 0 & $0 \%$ \\
\hline
\end{tabular}

Berdasarkan analisa kualitatif pada dokumen rekam medis rawat inap pasien BPJS kasus Penyakit Jantung di RS Islam Sultan Agung Semarang pada masingmasing review dapat diuraikan sebagai berikut:

a. Untuk review penulisan diagnosis spesifik menunjukkan 24 (88,9\%) konsisten dan $3(11,1 \%)$ tidak konsisten.

b. Untuk review kekonsistenan penulisan diagnosis menunjukkan 24 (88,9\%) konsisten dan $3(11,1 \%)$ tidak konsisten. c. Untuk review kekonsistenan pencatatan hal-hal yang telah dilakukan saat pengobatan dan perawatan menunjukkan $20(74,1 \%)$ konsisten dan $7(25,9 \%)$ tidak konsisten.

d. Untuk review adanya informed consent menunjukkan 27 (100\%) konsisten dan 0 (0\%) tidak konsisten.

Dari hasil tersebut dapat disimpulkan bahwa kekonsistenan pada analisa kualitatif terbanyak terdapat pada review adanya informed consent yaitu 27 (100\%) konsisten dan $0(0 \%)$ tidak konsisten.

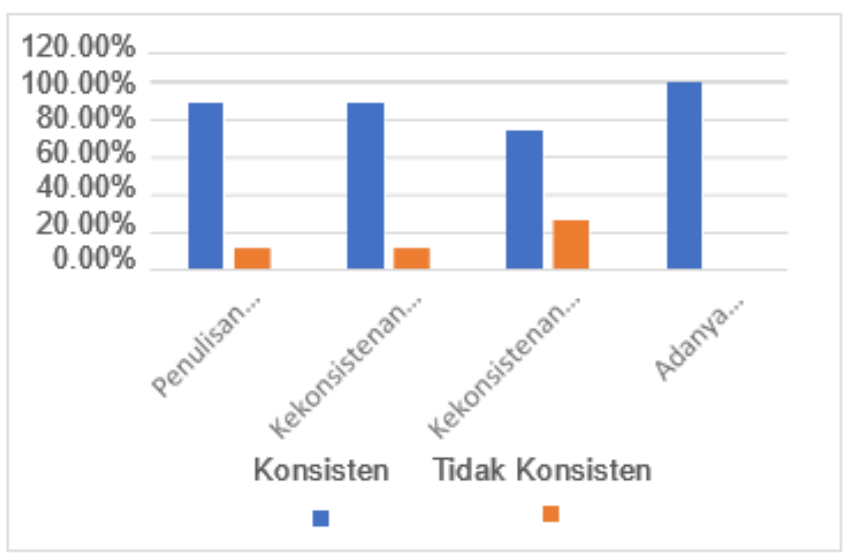

Grafik 2. Grafik Persentase Hasil Analisis Kualitatif Dokumen Rekam Medis Penyakit Jantung di RS Islam Sultan Agung Semarang

\section{B. Pembahasan}

1. Analisis Kuantitatif

Berdasarkan hasil penelitian yang telah dilakukan, analisis kuantitatif pada 27 sampel dokumen rekam medis pasien kasus Penyakit Jantung di Rumah Sakit 
Islam Sultan Agung Semarang. Hasil analisis kuantitatif yaitu didapatkan hasil kelengkapan review identifikasi sebanyak $21(77,8 \%)$ dan sebanyak 6 $(22,2 \%)$ dokumen tidak lengkap. Kelengkapan review autentikasi sebanyak 12 (44,4\%) dokumen lengkap dan sebanyak 15 (55,6\%) dokumen tidak lengkap. Kelengkapan reviewpencatatan sebanyak 19 (70,4\%) dokumen lengkap dan sebanyak 8 (29,6\%) dokumen tidak lengkap. Kelengkapan review pelaporan sebanyak $22(81,5 \%)$ dokumen lengkap dan sebanyak 6 (18,5\%) dokumen tidak lengkap.

Hasil penelitian ini menunjukkan ketidaklengkapan terbesar terdapat pada review autentikasi yaitu sebanyak 15 dokumen (55,6\%). Hal ini belum sesuai dengan Hatta yang menuturkan bahwasannya analisis kuantitatif bertujuan untuk menilai kelengkapan dan keakuratan rekam medis rawat inap maupun rawat jalan yang dimilki oleh rumah sakit atau sarana pelayanan kesehatan. ${ }^{(3)} \quad$ Untuk menjaga kelengkapan dan keakuratan rekam medis dibutuhkan adanya standar operasional prosedur dari tiap organisasi profesi atau yang telah ditetapkan oleh rumah sakit

\section{a. Review Identifikasi}

Dilakukan pengecekan terhadap setiap formulir terkait identitas pasien meliputi nomor rekam medis, nama, tanggal lahir / umur, jenis kelamin dan alamat lengkap. Dan didapatkan hasil pengamatan pada review identifikasi dari 27 sampel dokumen rekam medis rawat inap kasus Penyakit Jantung menunjukkan tidak lengkap review identifikasi sebanyak 6 (22,2\%) dokumen dan yang lengkap sebanyak 21 (77,8\%) dokumen. Ketidaklengkapan tertinggi terdapat pada review identifikasi terdapat pada item alamat yaitu sebanyak 5 $(18,5 \%)$ dan yang lengkap sebanyak 22 $(81,5 \%)$. Hasil penelitian ini selaras dengan penelitian (Rani dan Ernawati Dyah, 2015) di Rumah Sakit Permata Medika Semarang yang menunjukkan ketidaklengkapan pada pengisian jenis kelamin dan alamat sebanyak 64 (100\%) belum lengkap dan $0(0 \%)$ lengkap. ${ }^{(17)}$

b. Review Autentikasi

Pada pengecekan terhadap autentikasi pelayanan pasien berupa nama dokter, tanda tangan dokter, tanggal dan tempat pencatatan, didaptkan hasil review autentikasi pada 27 sampel dokumen rekam medis rawat inap kasus Penyakit Jantung menunjukkan ketidaklengkapan review autentikasi sebanyak 15 (55,6\%) dokumen dan kelengkapan sebanyak 12 $(44,4 \%)$ dokumen. Ketidaklengkapan terdapat pada item tanggal pencatatan yaitu sebanyak $9 \quad(33,3 \%)$ dan kelengkapan sebanyak 18 (66,7\%). Ketidaklengkapan tertinggi pada review autentikasi terdapat pada item tanggal pencatatan pada RM I (Ringkasan Masuk dan Keluar) yaitu sebanyak 9 $(33,3 \%)$ dan kelengkapan sebanyak 18 
(66,7\%), dikarenakan petugas yang berwenang mengisi formulir tersebut kurang teliti. Hasil penelitian ini tidak sejalan dengan penelitian (Pamungkas dkk.,2010) di Rumah Sakit PKU Muhammadiyah Yogyakarta yang menunjukkan ketidaklengkapan tertinggi review autentikasi terdapat pada item nama dokter pada lembar RM 4 yaitu sebanyak $94,68 \%$ dan ketidaklengkapan terendah terdapat pada item tanda tangan dokter pada lembar RM 1 yaitu sebanyak 2,84\%.(16) Secara umum pelaksanaan review autentikasi sesuai dengan Peraturan Menteri Kesehatan No.749a/MENKES/PER/XII/1985 pasal 5 mengenai setiap pencatatan harus dibubuhi tanda tangan. Menurut (Sudra, 2013) dalam pencatatan suatu pelaporan penting mencantumkan tanggal dan jam, hal ini terkait erat dengan peraturan pengisian rekam medis dan sangat penting pada saat diperlukan untuk pelacakan suatu kejadian. ${ }^{(6)}$

c. Review Pencatatan

Peneliti melakukan pengecekan terhadap pencatatan formulir dokumen rekam medis berupa ada tidaknya berkas tipe- $x$, coretan maupun tulisan yang tidak jelas atau tidak terbaca. Dari hasil pengamatan review pencatatan pada 27 sampel dokumen rekam medis rawat inap kasus Penyakit Jantung menunjukkan ketidaklengkapan review pencatatan sebanyak 8 (29,6\%) dokumen dan kelengkapan sebanyak 19 $(70,4 \%)$ dokumen. Hal ini sesuai dengan pendapat (Sudra, 2013) bahwa review teknik pencatatan diantaranya tulisan harus ditulis dengan menggunakan tinta permanen dan berwarna gelap sehingga tidak mudah luntur. ${ }^{(6)}$ Ketidaklengkapan tertinggi pada review pencatatan terdapat pada item ada dua coretan atau lebih yaitu sebanyak $6(22,2 \%)$ dan kelengkapan sebanyak 21 (77,8\%). Ketidaklengkapan tertinggi pada review pencatatan terdapat pada item ada dua coretan atau lebih yaitu sebanyak 6 $(22,2 \%)$ dokumen yaitu pada RM I (Ringkasan Masuk Keluar) dan RM 16A (Resume Keluar) sedangkan kelengkapan sebanyak $21 \quad(77,8 \%)$ dokumen sudah benar atau jelas. Kesalahan dalam pembetulan pencatatan tersebut dikarenakan tulisan yang keliru hanya dicoret saja kemudian diganti tulisan yang baru tanpa adanya tanda tangan dari pengubah hal ini sangat tidak diperbolehkan dalam prinsip pencatatan dokumen rekam medis. Hasil penelitian ini sejalan dengan penelitian (Rahayu dkk.,2013) di RSUD Pandan Arang Boyolali yang menunjukkan ketidaktepatan pendokumentasian yang benar pada penulisan jelas dan terbaca yaitu $6 \quad(10,71 \%)$ dokumen dan ketidaktepatan pada pembetulan kesalahan yaitu $16 \quad(71,43 \%)$ dokumen. ${ }^{(18)}$ Menurut (Sudra, 2013) apabila terjadi suatu kesalahan dalam penulisan maka untuk memperbaikinya tidak diperbolehkan menyebabkan tulisan yang salah tersebut tidak terbaca 
lagi atau hilang. Secara umum dianjurkan untuk melakukan pencoretan satu kali pada tulisan yang salah bisa dengan menggunakan penggaris sedangkan dalam menulis perbaikan pada tulisan yang salah sangat perlu mencantumkan tanggal dan tanda tangan yang melakukan perbaikan tulisan tersebut. ${ }^{(6)}$

\section{d. Review Pelaporan}

Peneliti melakukan pengecekan terhadap pelaporan yang ada dalam formulir dokumen rekam medis berupa anamnesa, pemeriksaan fisik, pemeriksaan penunjang, resume medis. Dari hasil pengamatan review pelaporan pada 27 sampel dokumen rekam medis rawat inap kasus Penyakit Jantung menunjukkan ketidaklengkapan review pelaporan sebanyak 5 (18,5\%) dokumen dan kelengkapan sebanyak 22 (18,5\%) dokumen. Menurut (Sudra, 2013) pada review autentikasi pengisan rekam medis berprinsip pada kejelasan penanggung jawab dengan pencantuman tanda tangan. Pelaporan yang terisi lengkap dan jelas sangat dibutuhkan dalam rumah sakit karena pelaporan ini merupakan bagian informasi yang penting sebagai bukti keabsahan secara hukum. ${ }^{(6)}$ Ketidaklengkapan tertinggi pada review pelaporan terdapat pada item pemeriksaan penunjang yaitu sebanyak $4(14,8 \%)$ dan kelengkapan sebanyak 23 $(85,2 \%)$. Ketidaklengkapan tertinggi pada review pelaporan terdapat pada item pemeriksaan penunjang yaitu sebanyak 4 (14,8\%) pada RM 16A (Resume Keluar) dan kelengkapan sebanyak 23 (85,2\%). Ketidaklengkapan pelaporan pada RM 16A (Resume Keluar) dikarenakan pada item pemeriksaan penunjang tidak dituliskan jenis pemeriksaannya ataupun hanya dituliskan dengan menggunakan kode pemeriksaan. Hasil penelitian ini tidak sejalan dengan penelitian (Utomo dan Suagiarsi, 2009) di Rumah Sakit Umum Daerah Kabupaten Karanganyar yang menunjukkan kelengkapan tertinggi review pelaporan penting terdapat pada formulir Ringkasan Masuk dan Keluar dan resume sejumlah 50 dokumen rekam medis dengan persentase 100\%. ${ }^{(19)}$ Menurut (Hatta, 2013) bahwa instruksi dokter atau pihak-pihak lain yang terlibat dalam perawatan pasien harus dilakukan pencatatan dan apabila ada tindakan harus ditulis dengan jelas. ${ }^{(3)}$

2. Analisis Kualitatif

Hasil penelitian yang telah dilakukan, pada analisis kualitatif pada dokumen rekam medis pasien kasus Penyakit Jantung di Rumah Sakit Islam Sultan Agung Semarang, yaitu didapatkan hasil review penulisan diagnosis spesifik sebanyak 24 (88,9\%) dokumen konsisten dan sebanyak 3 $(11,1 \%)$ dokumen tidak konsisten. Hasil review konsistensi penulisan diagnosis sebanyak 24 (88,9\%) dokumen konsisten dan sebanyak $3 \quad(11,1 \%$.) 
dokumen tidak konsisten. Hasil review informed consent sebanyak 100 (100\%) dokumen konsisten dan sebanyak $0(0 \%)$ dokumen tidak konsisten. Hasil ini sejalan dengan penelitian (Rani dan Ernawati Dyah, 2015) di Rumah Sakit Permata Medika Semarang yang menunjukkan pengisan dokumen rekam medis berdasarkan hasil analisis kualitatif terbanyak terdapat pada review pencatatan saat perawatan dan pengobatan yaitu menunjukkan kelengkapan sebanyak 35 (55\%) dan ketidaklengkapan sebanyak 29 (45\%). ${ }^{(17)}$ Namun, hal ini tidak sesuai dengan (Hatta, 2013) bahwa tujuan dari analisis kualitatif adalah tercapainya isi dokumen rekam medis agar terhindar dari masukan yang tidak konsisten atau taat asas maupun pelanggaran terhadap data atau rekaman yang akan berdampak pada hasil yang tidak akurat dan tidak lengkap. ${ }^{(3)}$

a. Review penulisan diagnosis spesifik

Peneliti melakukan pengecekan terhadap konsistensi serta kelengkapan spesifitas penulisan diagnosis yang telah ditulis oleh dokter. Dari hasil pengamatan review kelengkapan konsistensi diagnosis pada 27 sampel dokumen rekam medis rawat inap kasus Penyakit Jantung menunjukkan ketidakonsistenan sebanyak $3(11,1 \%)$ dokumen dan kekonsistenan sebanyak $24(88,9 \%)$ dokumen. Hasil ini sejalan dengan penelitian (Astanti, 2014) di Rumah Sakit Panti Wilasa Dr. Cipto
Semarang menunjukkan hasil analisis kualitatif pada review kelengkapan dan kekonsistensian diagnosis yaitu 76 (89\%) konsisten dan 9 (11\%) tidak konsisten. ${ }^{(20)}$ Kelengkapan dan kekonsistenan penulisan diagnosis sangat penting karena diagnosis tersebut nantinya akan dilakukan pengkodean oleh petugas coding rekam medis dan diagnosis ini juga berpengaruh terhadap tarif perawatan dan pengobatan pasien selama di rumah sakit.

b. Review kekonsistenan penulisan diagnosis

Pada pengecekan konsistensi penulisan diagnosis yaitu suatu penyesuaian atau kecocokan antara diagnosis dalam formulir satu dengan formulir lain yang diliat dari awal episode perawatan hingga akhir perawatan. Dari hasil pengamatan review konsistensi pencatatan diagnosis pada 27 sampel dokumen rekam medis rawat inap kasus Penyakit Jantung menunjukkan ketidakonsistenan sebanyak $3(11,1 \%)$ dokumen dan kekonsistenan sebanyak $24(88,9 \%)$ dokumen. Hasil penelitian tidak sejalan dengan penelitian (Setyani dan Sugiyanto, 2015) di Rumah Sakit Permata Medika Semarang yang menunjukkan hasil analisis kualitatif pada review kekonsistenan pencatatan diagnosis yaitu 56 (100\%) konsisten dan $0 \quad(0 \%)$ tidak konsisten. ${ }^{(21)}$ Menurut (Hatta, 2013) pengisian diagnosis yang tidak lengkap maka dapat menghambat 
pelayanan yang diberikan kepada pasien karena tidak adanya kesinambungan dari diagnosis awal pasien masuk sampai keluar yang menyebabkan pelayanan medis pasien menjadi tidak

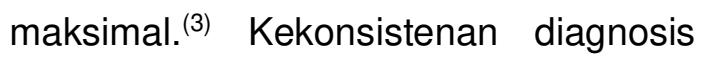
sangatlah penting karena apabila diagnosis dalam satu episode keperawatan memiliki diagnosis yang tidak tetap atau berubah- ubah maka petugas coding nantinya akan kesulitan dalam melakukan kodefikasi diagnosis utama yang tepat. Namun apabila terdapat suatu kondisi seperti diagnosis utama lebih dari satu maka petugas coding dapat menggunakan aturan reseleksi RULE-MB ICD-10 untuk memilih kode diagnosis utama dank ode diagnosis sekunder.

c. Review kekonsistensi hal-hal yang telah dilakukan saat pengobatan dan perawatan.

Dilakukan pengecekan terhadap pencatatan yang telah ditulis oleh tenaga medis maupun tenaga kesehatan terkait hal-hal yang dilakukan selama perawatan terhadap pasien. Dari hasil pengamatan review konsistensi hal-hal yang telah dilakukan saat pengobatan dan perawatan pada 27 sampel dokumen rekam medis rawat inap kasus Penyakit Jantung menunjukkan ketidakonsistenan sebanyak 7 (25,9\%) dokumen dan kekonsistenan sebanyak 20

dokumen.

Ketidakkonsistenan tersebut pada item anamnesa dan jenis tindakan yang tidak terisi pada RM I (Ringkasan Masuk Keluar) sedangkan pada RM 16A (Resume Keluar) terisi dan pada item pemeriksaan fisik seringkali pada RM 16A pengisian pemeriksaan fisik seperti tekanan darah, nadi, nafas, suhu tidak terisi sehingga informasi dalam formulir tersebut menjadi tidak lengkap. Hasil penelitian ini sejalan dengan penelitian (Anggara dan Sugiyanto, 2014) di RSUD Ungaran menunjukkan hasil analisa kualitatif pada review pencatatan hal yang dilakukan saat perawatan dan pengobatan yaitu 85 (85\%) konsisten dan $15 \quad(15 \%)$ tidak konsisten. ${ }^{(22)}$ Kekonsistenan hal-hal yang telah dilakukan saat pengobatan dan perawatan sangatlah penting karena informasi dalam dokumen rekam medis ini nantinya akan digunakan kembali ketika pelayanan pasien selanjutnya sehingga informasi perawatan dan pengobatan berksinambungan dan juga informasi yang lengkap terkait dengan pengobatan dan perawatan pasien selama di Rumah Sakit dapat digunakan sebagai bukti hukum secara tertulis di pengadilan apabila terjadi mal praktik maupun tuntutan keluarga atas pasien.

\section{d. Review informed consent}

Sedangkan pada pengecekan terhadap formulir informed consent sebagai bukti kesepakatan secara tertulis yang menunjukkan pasien setuju maupun tidak setuju terhadap tindakan medis yang akan dilakukan oleh dokter dalam proses perawatan dan 
pengobatan terhadap pasien. Dari hasil pengamatan review informed consent pada 27 sampel dokumen rekam medis rawat inap kasus Penyakit Jantung menunjukkan ketidakonsistenan sebanyak $0 \% \quad(0 \%)$ dokumen dan kekonsistenan sebanyak 27 (100\%) dokumen. Hasil Penelitian ini tidak sejalan dengan penelitian (Setyani dan Sugiyanto, 2015) di Rumah Sakit Permata Medika Semarang menunjukkan hasil analisis kualitatif pada review adanya informed consent yaitu 50 (89\%) konsisten dan 6 (11\%) tidak konsisten. ${ }^{(21)}$ Semua informed consent yang ada di dalam dokumen rekam medis sudah terisi dengan jelas. Hal ini sangat penting agar senantiasa menjaga kekonsistensian pengisian informed consent apabila dilakukan tindakan medis kepada pasien karena informed consent ini nantinya juga dapat digunakan sebagai bukti secara tertulis persetujuan tindakan kedokteran apabila pasien melakukan tuntutan kepada rumah sakit.

\section{KESIMPULAN DAN SARAN}

\section{A. Kesimpulan}

Berdasarkan hasil penelitian yang dilakukan di Rumah Sakit Islam Sultan Agung Semarang tahun 2020 dapat diambil kesimpulan bahwa: Analisis Kuantitatif dokumen rekam medis Penyakit Jantung secara keseluruhan didapatkan hasil kelengkapan terbesar terdapat pada review identifikasi yaitu sebanyak 21 (77,8\%) dokumen dan ketidaklengkapan tertinggi terdapat pada review autentikasi yaitu sebanyak 15 (55,6\%) dokumen pada formulir RM I (Ringkasan Masuk dan Keluar). Sedangkan pada Analisis Kualitatif dokumen rekam medis Penyakit Jantung secara keseluruhan didapatkan hasil kekonsistenan terbesar terdapat pada review adanya informed consent yaitu sebanyak 27 (100\%) dokumen dan ketidakkonsistenan terbesar terdapat pada review konsistensi pencatatan hal-hal yang dilakukan saat pengobatan dan perawatan yaitu sebanyak 7 (25,9\%) dokumen pada RM I (Ringkasan Masuk dan Keluar) dan RM 16A (Resume Keluar).

\section{B. Saran}

Saran yang dapat diterapkan dalam upaya peningkatan mutu pelayanan rekam medis rawat inap pasien BPJS di RSI Sultan Agung Semarang adalah 1) Review kuantitatif pada RM I (Ringkasan Masuk dan Keluar). Informasi tersebut berguna untuk mengidentifikasi kepemilikan dokumen rekam medis yang digunakan dalam pelayanan kesehatan. 2) Dokter penanggung jawab pasien (DPJP) memperhatikan kelengkapan informasi pada penulisan diagnosis dan penulisan nama serta tanda tangan sebagai bukti autentikasi terhadap tenaga medis dokter yang bertanggung jawab terhadap pasien. 3) Perawat senantiasa memperhatikan kelengkapan pengisian hal-hal yang dilakukan selama perawatan seperti halnya pemeriksaan fisik, asuhan keperawatan dll, serta mengisi nama dan tanda tangan perawat sebagai bukti autentikasi terhadap hal-hal yang telah dicatat dalam dokumen rekam medis pasien. 4) Petugas assembling lebih teliti dalam 
menganalisa dokumen rekam medis secara kuantitatif maupun kualitatif, mencatat kekurangan pada kartu kendali kemudian diberikan kepada unit yang terkait agar segera dilengkapi sehingga ketika dokumen rekam medis tersebut masuk ke bagian coding maka informasi yang dibutuhkan petugas dalam proses kodefikasi penyakit sudah lengkap.

\section{DAFTAR PUSTAKA}

1. Zahrawardani D, Herlambang $\mathrm{Ks}$, Anggraheny Hd. Analisis Faktor Risiko Kejadian Penyakit Jantung Koroner Di Rsup Dr Kariadi Semarang. J Kedokt Muhammadiyah. 2012;1(3).

2. Gemala Hatta. Penyediaan Sarana Kesehatan. Jakarta [Internet]. 2008;53(4798):160. Available From: Http://Etd.Repository.Ac.ld

3. Hatta G. Manajemen Sistem Informasi. Vol. 3, Universitas Indonesia. 2013. 45 P.

4. Indawati L. Analisis Akurasi Koding Pada Pengembalian Klaim Bpjs Rawat Inap Di Rsup Fatmawati Tahun 2016. J Manaj Inf Kesehat Indones. 2019;7(2):113.

5. Munsir N, Yuniar N, Nirmala F, Suhadi S. Analisis Pengisian Dokumen Rekam Medis Pasien Bpjs Rawat Inap Di Rumah Sakit Umum Dewi Sartika Tahun 2017. (Jurnal Ilm Mhs Kesehat Masyarakat). 2018;3(2).

6. Pujihastuti A, Sudra Ri. Hubungan Kelengkapan Informasi Dengan Keakuratan Kode Diagnosis Dan Tindakan Pada Dokumen Rekam Medis Rawat Inap. J Manaj Inf Kesehat Indones. 2014;2(2).

7. Maryati W, Wannay Ao, Suci Dp. Hubungan Kelengkapan Informasi Medis
Dan Keakuratan Kode Diagnosis Diabetes Mellitus. J Rekam Medis Dan Inf Kesehat. 2018;1(2):96-108.

8. Siswati S, Pratami SI. Hubungan Ketepatan Pemberian Kode Diagnosa Dan Tindakan Terhadap Persetujuan Klaim Bpjs. Indones Heal Inf Manag J. 2015;3(2):52-60.

9. Nugraha A. Asuhan Keperawatan Pada Tn. D Dengan Gangguan Sistem Kardiovaskuler: Congestive Heart Failure Di Ruang Kenanga Rumah Sakit Umum Daerah Ciamis Tanggal 15 Sd 19 Juni 2016.

10. Undang-Undang Nomer 44. UndangUndang Republik Indonesia Nomor 44 Tahun 2009 Tentang Rumah Sakit. Jakarta. 2009;(Rumah Sakit):40.

11. Menteri Kesehatan Ri. Permenkes Ri No. 269 Th. 2008 Tentang Rekam Medis. Menteri Kesehatan. 2008. P. 1-7.

12. Rakhmawati F, Rustiyanto E. Analisis Kebutuhan Petugas Rekam Medis Berdasarkan Beban Kerja Di Instalasi Rekam Medis Rs Aisyiah Muntilan. J Kesehat Vokasional. 2016;1(1):1.

13. Prajitno Sb. Metodologi Penelitian Kuantitatif [Internet]. Komunikasi Penelitian Kuantitatif Program Studi Jurnalistik \& Humas. 2008. P. 1-29. Available From: Http://Komunikasi.Uinsgd.Ac.ld

14. World Health Organization. Icd-10 Volume 2, Intruction Manual. Fam Pract Manag. 2011;18:39.

15. Wahyudi E, Hartati S. Case-Based Reasoning Untuk Diagnosis Penyakit 
Jantung. ljccs (Indonesian J Comput Cybern Syst. 2017;11(1):1-10.

16. Pamungkas Tw, Marwati T. Analisis Ketidaklengkapan Pengisian. 1992;17-28.

17. Rani DI, Ernawati D,. Analisis Kuantitatif dan Kualitatif Dokumen Rekam Medis Rawat Inap Pada Pasien Dengue Haemorrhagic Fever di Rumah Sakit Permata Medika Semarang Periode Triwulan I Tahun 2015. 2015;15.

18. Rahayu Sn, Sugiarsi S. Analisis Kuantitatif Dokumen Rekam Medis Pasien Rawat Inappada Kasus Chronic Kidney Disease Triwulan Ivdi Rsud Pandan Arang Boyolali. Rekam Medis. 2014;7(2).

19. Utomo Hd, Sugiarsi S. Analisis Kuantitatif Dokumen Rekam Medis Pasien Hypertensi Di Rumah Sakit Umum Daerah Kabupaten Karanganyar. Rekam Medis. 2009;3(2).

20. Astanti Np. Analisis Kuantitatif Dan
Kualitatif Dokumen Rekam Medis Rawat Inap Pada Kasus Penyakit Demam Tifoid Dan Paratifoid Triwulan I Periode 2014 Di Rumah Sakit Panti Wilasa Dr. Cipto Semarang.

21. Dwi Sf. Analisa Kuantitatif Dan Kualitatif Dokumen Rekam Medis Rawat Inap Pada Kasus Sectio Caesaria Di Rumah Sakit Permata Medika Semarang Triwulan I Tahun 2015. 2015;

22. Anggara Jd, Sugiyanto Z. Analisa Kuantitatif Dan Kualitatif Dokumen Rekam Medis Rawat Inap Pada Penyakit Diabetes Melitus Pada Triwulan 2 Di Rsud Ungaran Tahun 2014.

23. Yuliani N. Analisis Keakuratan Kode Diagnosis Penyakit Commotio Cerebri Pasien Rawat Inap Berdasarkan Icd-10 Rekam Medik Di Rumah Sakit Islam Klaten. Infokes (Jurnal IIm Rekam Medis Dan Inform Kesehatan). 2010;1(1):17-31. 